\section{Plugging the brain drain}

China produces fine scientists, but too many go abroad for training and do not return.

David Cyranoski visits a programme that aims to give scientific high-fliers a reason to stay put.

iqun Luo is in demand. It's seven in the morning and a queue is already forming for his cell-biology class at the Shanghai Institutes for Biological Sciences (SIBS). Luo, a visiting lecturer, is not due for another hour and a half, but the students have arrived early to get the best seats.

Back in his laboratory at Stanford University in California, Luo's research team jokes about his new rock-star status. But, like real rock fans, many of Luo's Chinese students want to follow in his footsteps. Young Chinese who are serious about science often feel that they have to train abroad - and most do not return. Luo's classes are designed to persuade them to stay.

The US National Science Foundation estimates that around 33,000 Chinese students enrolled in graduate programmes in the United States in 1999. And of Chinese students receiving their doctorates that year, almost $90 \%$ said that they planned to stay in the United States. If China is to realize its ambitious plans to expand life-sciences research (see Nature 410, 10-12; 2001), it must halt this brain drain.

\section{Stimulation on a shoestring}

Luo's lectures are part of a new graduate programme in the biological sciences that is bringing world-class education to China, and might begin to stem the flow. The budget of US\$20,000 a year is just enough to cover guest lecturers' expenses. But with this shoestring funding the organizers are creating a course that is stimulating students and stirring up the Chinese education system.

It is all the idea of Yi Rao, a neuroscientist at Washington University in St Louis, Missouri, and Jiarui Wu, a molecular biologist at SIBS. Wu gained his PhD at the Swiss

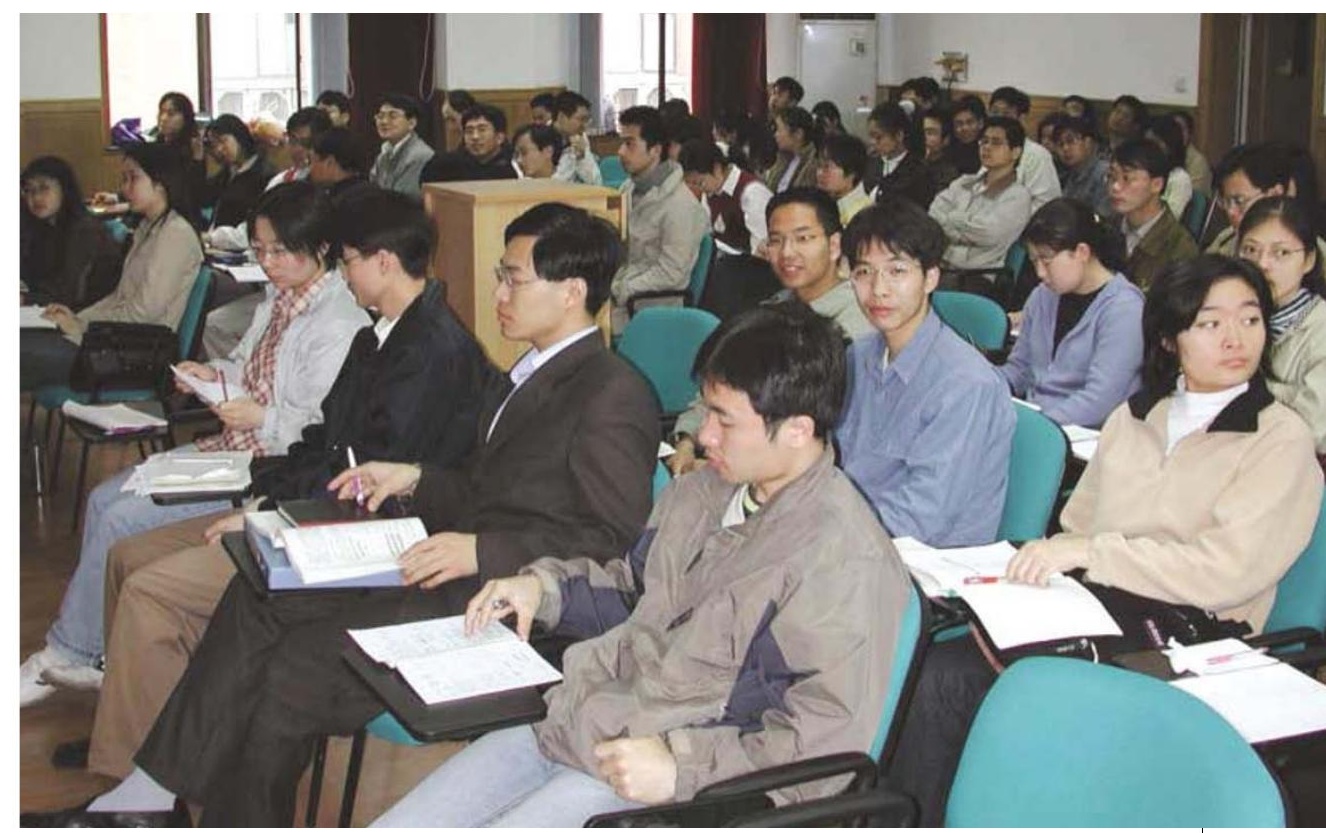

Wake-up call: expatriate scientists lecturing on the latest research have proved a hit with students.

Federal Institute of Technology in Zurich, and then carried out research at the State University of New York in Syracuse. "After getting that great education overseas, I felt a duty to contribute to first-class graduate education here," he says.

Together with Rao, he persuaded the Chinese Academy of Sciences to fund a oneyear programme of graduate lectures in molecular and cell biology. The courses, which began in 2000, are taught in Chinese but the outlook is global. All the 25 lecturers have worked outside China. Fifteen are based in the United States and return for a week each year to teach classes.

The course is an eye-opener for students used to lecturers working from textbooks and papers in Chinese journals. "Here the professors show us their latest research, so we know it is cutting-edge," says Ning Li, a firstyear student. The students also appreciate the relaxed atmosphere. "In a traditional class we cannot ask the professors many questions," says second-year student Yan Li. "We do not want to offend them."

Lecturers on the programme also make students examine scientific papers with a critical eye. Rao, for example, challenges his
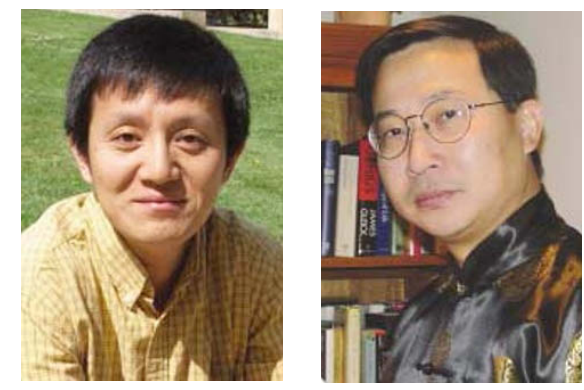

Liqun Luo (left) and Yi Rao are bringing world-class education to Chinese students. students to criticize a Nature paper. "The students used to worship papers in journals like Nature, Science and Cell," says Rao. "It is important that they think about the content of a paper and not get carried away by its publication in a fashionable journal."

\section{Will it work?}

Like any new course, the programme has glitches. Some students complain that graduates of previous courses who run discussion sessions cannot explain all the material they have to deal with. Others say that the content of the different classes is hard to tie together. And lecturers acknowledge that the class size of 200 is too big to allow students easy access to the teacher.

These problems do not seem to be dampening the students' enthusiasm, but is the programme going to persuade them to stay? Despite Nang Li's praise for the course, he is in no doubt about what he wants to do next: "I will go to the United States to do postdoctoral work." Many students say the same.

Comments such as these do not surprise the lecturers. "I don't think a good teaching programme alone can keep more top researchers in China," says Bai Lu, a neuroscientist at the National Institute of Child Health and Human Development in Bethes$\mathrm{da}$, Maryland, and a lecturer on the course.

But the Chinese government is pouring money into biological science and seeking to commercialize the results of research. If the SIBS programme can be emulated elsewhere in China as well, it could provide another reason to stay. And if it generates a flow of talented home-grown postgraduates, it might even convince more expatriates to return to collaborate with this highly trained workforce.

David Cyranoski is Nature's Asian-Pacific correspondent. 